\title{
自然海水中ステンレス鋼の自然電位貴化におよぼす バクテリアの影響
}

\author{
石原靖子*, 辻川茂男* \\ * 東京大学大学院工学系研究科金属工学専攻
}

\begin{abstract}
Effect of Bacteria Combined with Diatom on Ennoblement of Electrode Potential for Stainless Steels in Natural Sea Water
\end{abstract}

\author{
Yasuko Ishihara* and Shigeo Tsujikawa* \\ * Department of Metallurgy, School of Engineering, \\ The University of Tokyo
}

\begin{abstract}
When stainless steels samples are immersed in natural sea water, an ennoblement of the electrode potential ( $E_{\mathrm{sp}}$ ) up to approximately $400 \mathrm{mV}$ vs. SCE can occur, due to the development of biofilm on the samples. The main organisms in the biofilm include bacteria and diatom. In this paper, it was investigated the relationship between the ennoblement of $E_{\mathrm{sp}}$ and bacteria species in the biofilm, and the interaction between bacteria and diatom in the $E_{\mathrm{sp}}$ ennoblement. To study effect of various bacteria species in the biofilm on the ennoblement of $E_{\mathrm{sp}}$, type 316 stainless steel samples were immersed in $0.4 \mu \mathrm{m}$ filtered natural sea water, where the filtering was expected to restrict bacteria as the only organisms in the water. Under this condition, ennoblement of $E_{\mathrm{sp}}$ up to $400 \mathrm{mV}$ vs. SCE could not be attained, and the need of other organisms in biofilm, besides bacteria, to promote ennoblement was shown. The analysis of biofilm, formed in natural sea water, on sample with ennobled $E_{\mathrm{sp}}$, detected the presence of sulfate-reducing bacteria, acidic and neutral sulfur-oxidizing bacteria ( $\mathrm{A}-\mathrm{SOB}$ and $\mathrm{N}-\mathrm{SOB}$, respectively). It was also observed that the density of N-SOB was high all through the year. To study effect of SOB on ennoblement of $E_{\mathrm{sp}}$, type 304 stainless steel was immersed in solutions containing Thiobacillus thioparus (as N-SOB) and T.thiooxidans (as A-SOB). Remarkable $E_{\text {sp }}$ ennoblement was induced by $\mathrm{N}-\mathrm{SOB}$, but not by A-SOB. However, as the density of attached N-SOB on the ennobled sample was too much higher than the density to be attained under immersion in unfiltered natural sea water, the ennoblement of $E_{\mathrm{sp}}$ was concluded not to occur by that single bacteria. When samples were transferred to diatom containing solution, after immersion in natural sea water for a few days, to promote attachment of bacteria on the samples, the $E_{\mathrm{sp}}$ of the samples presented high values, similar to the values observed for samples immersed in natural sea water in summer. After immersion in diatom containing solution, the effect of the density of attached bacteria and diatom on $E_{\mathrm{sp}}$ was investigated. For $E_{\mathrm{sp}}$ ennoblement up to $200 \mathrm{mV}$ vs. SCE, the density of attached bacteria increased up to about $3.5 \times 10^{4}$ $\mathrm{pg} / \mathrm{cm}^{2}$, with increasing density of diatom. For $E_{\mathrm{sp}}$ ennoblement higher than $200 \mathrm{mV}$ vs. $\mathrm{SCE}$, it is suggested that the attachment of diatom on the sample plays a more important role.
\end{abstract}

Key words: corrosion, stainless steel, ennoblement of electrode potential, biofilm, natural sea water, sulfate reducing bacteria, sulfur-oxidizing bacteria, iron-oxidizing bacteria, diatom

* T113-8656 東京都文京区本郷 7-3-1 (7-3-1, Hongo, Bunkyo-ku, Tokyo, 113-8656 Japan) 


\section{1.はじめに}

自然海水中に浸漬されたステンレス鋼の表面には海水 中に含まれる微生物およびこれらの分解産物からなるバ イオフィルムが形成され，夏期なら 10 日程で，自然浸 漬電位（ $E_{\mathrm{sp}}$ ）が約 $400 \mathrm{mV}$ vs. SCE まで貴化する ${ }^{1)}$ 。 試験片に付着した様々な微生物のうち, 珪藻をバクテリ ア類と組み合わせることにより実験室でも大きな $E_{\mathrm{sp}}$ 貴 化を再現できることや，その貴化量は珪藻付着密度・珪 藻種に大きく依存することをこれまでに報告した ${ }^{2)}$ 。本 研究では, $E_{\mathrm{sp}}$ 貴化に対するバクテリアの影響を検討す るため, 第一に自然海水中におけるバクテリア類単独の 貴化効果を調べた。また, 試験片に付着しているバクテ リア種の調查をおこない，その結果に基づいた特定のバ クテリアによる $E_{\mathrm{sp}}$ 貴化再現実験をおこない，珪藻とバ クテリアの共存効果についても検討した。

\section{2. 実験方法}

\section{1 試 験 片}

静岡県清水市の東京商船大学清水臨海実験実習所（以 下, 清水という）における自然海水浸漬および実験室に おける試験には, 前報同様の Type 316 鋼試験片を用い た ${ }^{2)}$ 。一部の実験室試験には, 厚さ $2.0 \mathrm{~mm}$ の Type 304 ステンレス鋼板（304 鋼試験片）を用いた。寸法は, 懸濁液浸漬部が $10 \times 10 \mathrm{~mm}$, 柄の部分の幅が $3 \mathrm{~mm}$, 全長が $30 \mathrm{~mm}$ である。いずれも， $\mathrm{SiC}$ 紙\# 800 まで湿 式研磨し，アセトンによる脱脂・水洗ののち，24 時間 以上乾燥し，実験に用いた。

\section{2 バクテリア類のみを含む自然海水および滅菌海 水中における浸漬試験}

清水において，ポンプで波み上げ られた海水を，3〜 30 $\mu \mathrm{m}$ の各種孔 径フィルター（TCP 30 SINE, TCYEBSSINE, TCYEHSSINE : 東洋濾紙(株)) を経て, 最終的に 孔径 $0.4 \mu \mathrm{m}$ のフィルター $(611102$ : 野村マイクロサイエンス(株)) を通過させることで，生物としては バクテリア類のみを含むと期待され る海水 (以下, $0.4 \mu \mathrm{m}$ 万過海水) を得た。また, 最終フィルターの孔 径を $\phi 0.2 \mu \mathrm{m}$ （611101：同）にす ることで，生物を含まないと期待さ れる海水 (以下, $0.2 \mu \mathrm{m}$ 万過海水) も作成した。この過程をまとめたも のが Fig. 1 である。以上の海水は, $150 \times 150 \times 200 \mathrm{~mm}$ のメタクリル樹

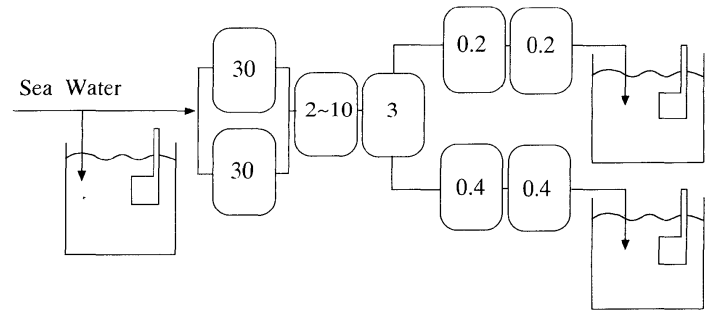

Fig.1 Schematic diagram of the system for filtering natural sea water. The number in each square is the pore size of filters in $\mu \mathrm{m}$.

脂製の水槽に約 $1 \sim 2 l / \mathrm{min}$ で配水し, オーバーフロー 分はそのまま排水する一過性とした。316 鋼試験片は 1998 年 4 月から 1999 年 2 月まで各月内で 6 27 日間浸 漬した。

\section{3 自然海水浸漬下で試験片に付着したバクテリア の調查}

清水において試験片に付着したバクテリア類のうち, $E_{\mathrm{sp}}$ 貴化にかかわると考えられる酸性および中性硫黄酸 化細菌（それぞれA-SOB, N-SOB とする), 硫酸塩還 元細菌(SRB), 鉄酸化細菌(IOB) について調查した。 1998 年 4 月より 1999 年 2 月までの各月で 10 14 日間, 清水において，前報 ${ }^{2}{ }^{2}$ 同様に浸漬した 316 鋼試験片に付 着したバイオフィルムをカミソリで剝ぎ取り, $10 \mathrm{ml}$ の 滅菌海水中に懸濁させ，この液中に含まれる，それぞれ の細菌密度を MPN (most probable number, 最確数) 法 ${ }^{3)}$ で定量した。それぞれの培養液組成を Table 1 に 示す。

Table 1 Culture mediums for A-SOB, N-SOB, SRB and IOB.

\begin{tabular}{|c|c|c|c|c|c|}
\hline & & $\mathrm{A}-\mathrm{SOB}^{16}$ & $\mathrm{~N}-\mathrm{SOB}^{16)}$ & $\mathrm{SRB}^{16)}$ & IOB(modified) \\
\hline $\mathrm{Na}_{2} \mathrm{~S}_{2} \mathrm{O}_{3} \cdot 5 \mathrm{H}_{2} \mathrm{O}$ & $\mathrm{g}$ & & 10.0 & & \\
\hline $\mathrm{Na}_{2} \mathrm{~S}_{2} \mathrm{O}_{3}$ & $\mathrm{~g}$ & 10.0 & & & \\
\hline $\mathrm{KH}_{2} \mathrm{PO}_{4}$ & $\mathrm{~g}$ & 0.2 & 0.25 & & \\
\hline $\mathrm{K}_{2} \mathrm{HPO}_{4}$ & $\mathrm{~g}$ & & 0.25 & 0.2 & 0.5 \\
\hline $\mathrm{KCl}$ & $\mathrm{g}$ & & & & 0.1 \\
\hline $\mathrm{NaCl}$ & $\mathrm{g}$ & & & & 15 \\
\hline $\mathrm{NH}_{4} \mathrm{Cl}$ & $\mathrm{g}$ & 0.1 & 0.5 & & \\
\hline$\left(\mathrm{NH}_{4}\right)_{2} \mathrm{SO}_{4}$ & $\mathrm{~g}$ & & & & 3.0 \\
\hline $\mathrm{MgSO}_{4} \cdot 7 \mathrm{H}_{2} \mathrm{O}$ & $\mathrm{g}$ & 0.25 & & & 0.5 \\
\hline $\begin{array}{l}\mathrm{Ca}\left(\mathrm{NO}_{3}\right)_{2} \\
\mathrm{FeCl}_{3} \cdot 6 \mathrm{H}_{2} \mathrm{O}\end{array}$ & $\begin{array}{l}\mathrm{g} \\
\mathrm{g}\end{array}$ & & 0.001 & & 0.01 \\
\hline $\mathrm{FeSO}_{4} \cdot 7 \mathrm{H}_{2} \mathrm{O}$ & $\mathrm{g}$ & & & 0.2 & 20 \\
\hline yeast extract & $\mathrm{g}$ & & & 1.0 & \\
\hline Bacto pepton & $\mathrm{g}$ & & & 2.0 & \\
\hline sodium lactate & $\mathrm{g}$ & & & 3.5 & \\
\hline $\mathrm{L}(+)$ - ascorbic acid sodium salt & $\mathrm{g}$ & & & 0.2 & \\
\hline Bacto agar & $\mathrm{g}$ & & & 30 & \\
\hline sterilized sea water & $\mathrm{ml}$ & 1000 & 1000 & 1000 & \\
\hline distilled water & $\mathrm{ml}$ & 56 & 70 & 75 & $\frac{1000}{30}$ \\
\hline
\end{tabular}




\section{4 バクテリア㦟濁液における浸漬試験}

\section{4.1 特定バクテリアの入手と培養}

Thiobacillus thioparus (IAM No. 12113) \& Thiobacillus thiooxidans（JCM No.3866）はそれぞ れ, 東京大学分子細胞生物学研究所細胞 - 機能高分子セ ンターIAM カルチャーコレクションと理化学研究所微 生物系統保存施設より購入した。これらのバクテリアを 2. 4. 3 に述べる方法にてアクリジン・オレンジで染色し たのち，蛍光顕微鏡観察した写真を Fig. 2 に示す。両 バクテリアとも $25^{\circ} \mathrm{C}$ で一定密度に達するまで培養し， 実験に用いた。培養液組成を Table 2 に示す。

\subsection{2 浸 清試 験}

バクテリア懸濁液 $100 \mathrm{~m} l$ を $200 \mathrm{~m} l$ ビーカーに入れ， この中に 304 鋼試験片を浸漬し，シリコン栓でふたを する。ふたには $\phi 15 \mathrm{~mm}$ の孔をあけ，この開孔部を通 気性に優れ，空中浮遊菌をとりこまない $0.5 \mu \mathrm{m}$ のメン ブレンフィルター（ミリラップ：日本ミリポア社）て 覆ってある。ビーカー底に沈めた䚓䢁子をマグネチック スターラーで回転させ，液を鲵拌することで，通気とバ
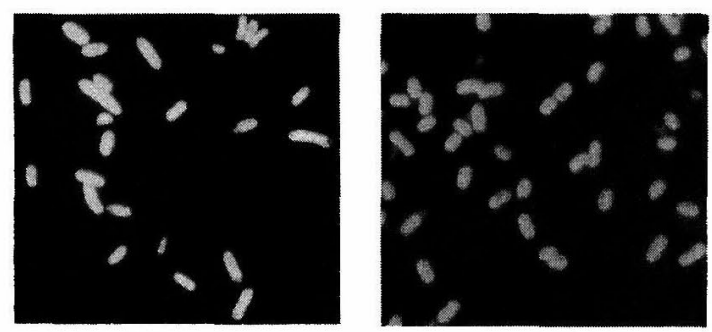

a. Thiobacillus thiooxidans

b. Thiobacillus thioparus

$4 \mu \mathrm{m}$

Fig.2 Acridine orange stained cells of Thiobacillus thiooxidans (a) and T. thioparus (b).

Table 2 Culture mediums for Thiobacillus thiooxidans and $T$. thioparus.

\begin{tabular}{l|c|c|c}
\hline & & $\begin{array}{c}\text { Thiobacillus } \\
\text { thiooxidans }\end{array}$ & $\begin{array}{c}\text { Thiobacillus } \\
\text { thioparus }\end{array}$ \\
\hline $\mathrm{Na}_{2} \mathrm{HPO}_{4} \cdot 12 \mathrm{H}_{2} \mathrm{O}$ & $\mathrm{g}$ & & 1.2 \\
$\mathrm{KH}_{2} \mathrm{PO}_{4}$ & $\mathrm{~g}$ & 3.0 & 1.8 \\
$\mathrm{MgSO}_{4} \cdot 7 \mathrm{H}_{2} \mathrm{O}$ & $\mathrm{g}$ & 0.5 & 0.1 \\
$\left(\mathrm{NH}_{4}\right)_{2} \cdot \mathrm{SO}_{4}$ & $\mathrm{~g}$ & 0.2 & 0.1 \\
$\mathrm{CaCl}_{2} \cdot 2 \mathrm{H}_{2} \mathrm{O}$ & $\mathrm{mg}$ & 250.0 & 0.03 \\
$\mathrm{FeSO}_{4} \cdot 7 \mathrm{H}_{2} \mathrm{O}$ & $\mathrm{mg}$ & 10.0 & \\
$\mathrm{FeCl}_{3} \cdot 6 \mathrm{H}_{2} \mathrm{O}$ & $\mathrm{g}$ & & 0.02 \\
$\mathrm{MnSO}_{4} \cdot 5 \mathrm{H}_{2} \mathrm{O}$ & $\mathrm{g}$ & & 0.02 \\
sulfur* & $\mathrm{g}$ & 10.0 & 10.0 \\
$\mathrm{Na}_{2} \mathrm{~S}_{2} \mathrm{O}_{3}$ & $\mathrm{~g}$ & & 1000 \\
distilled water & $\mathrm{ml}$ & 1000 & 7.0 \\
\hline $\mathrm{pH}$ & & 3.0 & \\
\hline \multicolumn{2}{|c|}{}
\end{tabular}

* Sulfur is sterilized separately. $\left(121^{\circ} \mathrm{C}, 15 \mathrm{~min}\right)$
クテリアの浮遊状態を保った。液温は $25^{\circ} \mathrm{C}$ に保った。

\section{4.3 バクテリア密度の定量}

1）採濁液中のバクテリア密度

バクテリア䯚濁液を $2.7 \mathrm{~m} l$ 採取し, $0.2 \mu \mathrm{m}$ メンブ レンフィルターでろ過した $0.1 \%$ アリジンオレンジ溶 液を $0.3 \mathrm{ml}$ 加え，1〜2 分染色する。この液をシリンジ に取り, 孔径 $0.2 \mu \mathrm{m} ・ \phi 25 \mathrm{~mm}$ のニクリポア・ブ ラック・メンブレンフィルター (110656: 野村マイクロ サイエンス(株)）を通すことで，バクテリアをフィル タ一上に集める。これを，ろ過面を上にしたままスライ ドガラスにのせ, カバーガラスをかけて, $\times 1,000$ で蛍 光顕微鏡観察（ $\beta$ 励起）する。バクテリアは暗視野の中 で橙色に光って観察される。ここで， $80 \times 80 \mu \mathrm{m}(10 \times$ 10万形) の接眼ミクロメーターを用いて, 総計数值が 200 に達するまで, 少なくとも5 回視野を変えて测定す る。そして次式によりバクテリア密度を算出する。

密度 $($ 細胞数 $/ \mathrm{ml})=\mathrm{ab} /(\mathrm{cd})$

ここに, $\mathrm{a}: 1$ 万形中のバクテリア細胞数, $\mathrm{b}$ : フィル ター万過面積 $\left(\mu \mathrm{m}^{2}\right), \mathrm{c}:$ 万過した溶液量 $(\mathrm{ml})$, $\mathrm{d}:$ 方形面積 $\left(\mu \mathrm{m}^{2}\right)$ 。

2）バクテリア懸濁液中で試験片に付着したバクテリ ア密度

304 鋼試験片に付着したバイオフィルムをカミソリで はぎ取り, $2.5 \mathrm{~m} l$ の滅菌海水に希釈したものを原液と する。これをエンドトキシンフリー蒸留水（5A：生化 学工業(株)）で適当に希釈し，市販のキット（エンド スペシーES- 6 セットおよび Et- 2 セット：生化学工業 (株)）を用いて, リポ多糖（LPS）を定量した。海洋 細菌の大部分はグラム陰性菌であることが知られている が，LPS はグラム陰性菌に固有に含まれる4)。このよ うな LPS 值を海洋細菌量として採用した。

\subsection{4 バクテリア懸濁液中の $\mathrm{SO}_{4}{ }^{2}-$ の定量}

懸濁液を蒸留水で適当に希釈し, 高速液体クロマトグ ラフィー（D-7000 HPLC：(株)日立製作所）にて定量 した。

\section{5 バクテリア類および珪藻による電位貴化再現試 験}

前報 ${ }^{2)}$ と同様に, Stage I として 316 鋼試験片の到 達電位（ $E_{\mathrm{sp}, \mathrm{I}}$ ）が 19〜73 mV vs. SCE になるまで, 自 然海水中に浸漬した。付着微生物は，ほとんどバクテリ ア類のみと期待される。次の Stage IIでは, この試験片 を実験室に持ち帰り，種々の密度まで培養をすすめた珪 藻 Nitzchia sp.B 懸濁液に浸漬した。この珪藻は清水に おいて， $E_{\mathrm{sp}}$ が貴化しやすい夏の優先種である ${ }^{2)}$ 。 Stage II 終了後, 試験片に付着した珪藻密度は前報 ${ }^{2)}$ と 同様に,またバクテリア密度は2.4.3の2）に示した LPSにより定量した。 


\section{3. 実験結果と考察}

\section{1 バクテリア類単独の $E_{\mathrm{sp}}$ 貴化効果}

自然海水中におけるバクテリア類単独の $E_{\mathrm{sp}}$ 貴化効果 を調べるため, バクテリア類以外の生物を除いた 0.4 $\mu \mathrm{m}$ 万過海水に試験片を浸漬し， $E_{\mathrm{sp}}$ の経時変化を測定 した。その結果を，同時期に測定した非ろ過自然海水お よび，一般的に滅菌海水とされている $0.2 \mu \mathrm{m}$ 万過海水 中のデー夕と併せて Fig. 3 に示す。 $0.4 \mu \mathrm{m}$ 万過海水で は， $0.2 \mu \mathrm{m}$ 万過海水と比較すると若干貴化がみられる ものの, 自然海水と比較すると貴化程度は小さい。 Fig. 3 の実験終了時における, 試験片付着バクテリア 量と $E_{\mathrm{sp}}$ との関係を調べた結果を Fig. 4 に示す。0.2 $\mu \mathrm{m}$ 万過海水中では, バクテリアはほとんど付着してお らず， $E_{\mathrm{sp}}$ 貴化も認められない。一方， $0.4 \mu \mathrm{m}$ 万過海 水之自然海水とのいずれにおいても，付着量が多くなる ほど $E_{\mathrm{sp}}$ も貴化しているが，同程度の付着量であれば，

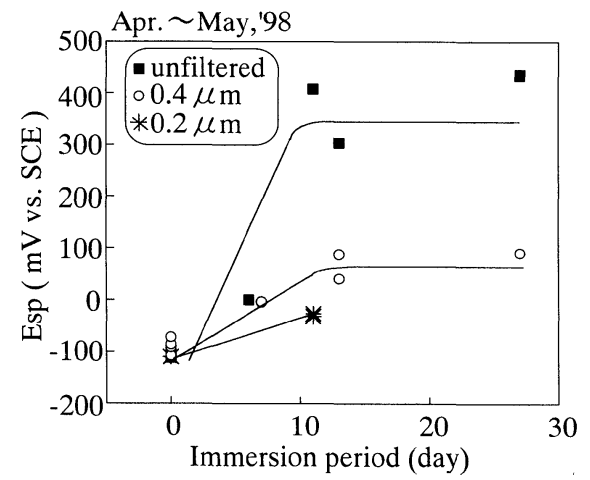

Fig.3 Time variation of $E_{\mathrm{sp}}$ for Type 316 steel in natural (unfilterd) sea water, 0.4 and $0.2 \mu$ $\mathrm{m}$ filtered sea water.

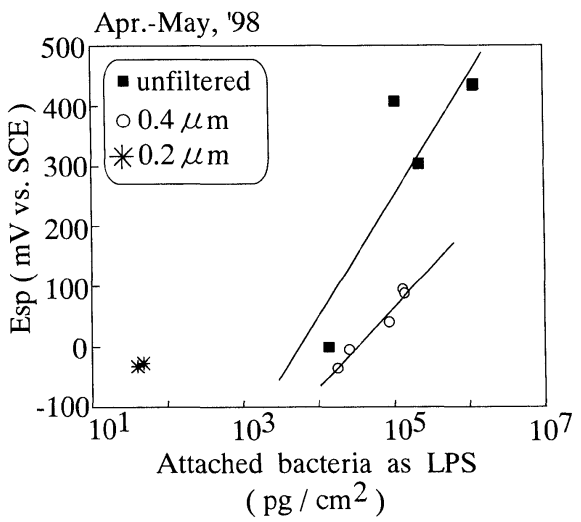

Fig.4 Relationship between $E_{\mathrm{sp}}$ and density of attached bacteria on Type 316 steel in natural (unfiltered) and filtered sea water.
自然海水中において，より大きな $E_{\mathrm{sp}}$ 貴化がみられた。 以上は1998 年の 4〜 5 月の結果であるが，年間を通し て, 自然海水および $0.4 \mu \mathrm{m}$ ろ過海水浸漬下で調査した $E_{\mathrm{sp}}$ とバクテリア付着量との関係を Fig. 5 に示す。それ ぞれの海水中では，いずれの月でも，バクテリア付着量 が多いほど $E_{\mathrm{sp}}$ はより大きく貴化しており，かつ冬期よ り夏期に貴化の程度は大きい。この現象は, 自然海水に 浸漬された試験片でみられる，冬期よりも夏期に貴化し やすい ${ }^{1)}$ という季節変動とよく対応している。しかし, $0.4 \mu \mathrm{m}$ 万過海水中では, 夏期 2 週間浸漬しても $E_{\mathrm{sp}}$ は 約 $200 \mathrm{mV}$ vs. SCE にとどまった。Fig. 4 の結果と同 様, $400 \mathrm{mV}$ という高い電位に達するためには, バクテ リア類に加えて，他の微生物の共存が必要である。

\section{2 自然海水浸漬中に試験片に付着したバクテリア の調査}

2.3 に述べた調查による, 各バクテリア付着密度と 316 鋼試験片の $E_{\mathrm{sp}}$ との季節変動を Fig. 6 に示す。 $\mathrm{N}-\mathrm{SOB}$ と SRB は年間を通して検出されたが，前者の 密度は, 各月とも析違いに多かった。A-SOB は春から 夏にかけてのみ検出された。IOB は年間を通じて検出 されなかった。

IOB は二価鉄を三価鉄に酸化することで ATP を生成 しているが，この酸化はバルク液中の硫酸イオン濃度に 対する塩化物イオンまたは他の陰イオン濃度の割合が高 いと抑制される ${ }^{5)}$ 。したがって, 塩化物イオン濃度比が 高い海水環境においては, IOB は存在しないと考察し ている報告 ${ }^{6)}$ もある。また，このバクテリアの至適 $\mathrm{pH}$ が酸性であることも， $\mathrm{pH} 8$ という海水環境では増殖し にくい要因と考えられる。

$\mathrm{SRB}$ も N-SOB 同様, 年間を通して検出されたが, その密度は $10^{3} \mathrm{cell} \mathrm{s} / \mathrm{m} l$ 以下と低い。SRB は偏性嫝気

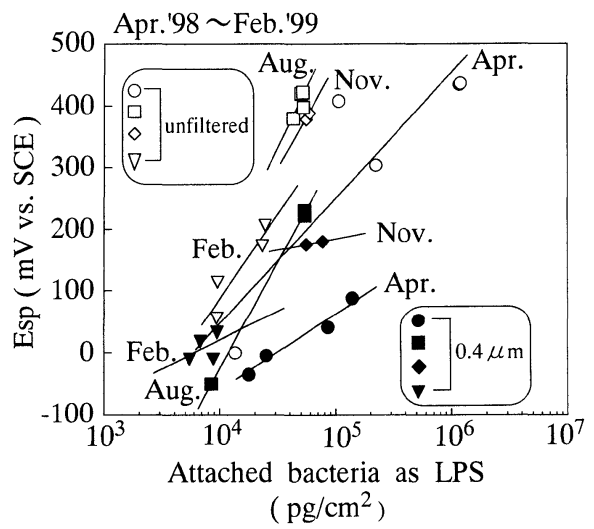

Fig.5 Monthly relationship between $E_{\mathrm{sp}}$ and density of attached bacteria on Type 316 steel in natural (unfiltered) and filtered $(0.4 \mu \mathrm{m})$ sea water. 
性菌で, 主に沿岸海洋・干潟や湖沼の嫌気的な堆積物や 水田土壤に分布している7) ため, 酸素を含む自然海水環 境には適さない可能性が考えられる。

A-SOB は 5 9 月にのみ検出されたが，その密度は $10^{2}$ cells $/ \mathrm{m} l$ 弱と低かった。このバクテリアの至適 $\mathrm{pH}$ は 3 であるので, $\mathrm{pH} 8$ という海水環境では増殖しにく いのかもしれない。これに比べ，中性 $\mathrm{pH}$ 条件を好む N-SOB は，調查したいずれの月でも $10^{5} \sim 10^{7}$ cells/ $\mathrm{m} l$ の高密度で検出された。

\section{3 硫黄酸化細菌 (SOB) 単独の $E_{\mathrm{sp}}$ 貴化効果}

3.2 で調查したバクテリア類のうち, 特に高密度で あった N-SOB を含み，かつこれまで研究例の少ない SOB に着目し，その単独の貴化効果を調べるために，

A-SOB または N-SOB を純粋培養した懸濁液中に試験 片を浸漬し， $E_{\mathrm{sp}}$ を経時的に測定した。この際に用いる バクテリアは，清水にて試験片に付着したバイオフィル 厶中から単離・純粋培養するのが望ましいが，それに要 する時間や同定の難しさなどを考慮の上，国内の菌株保 存機関より以下の 2 種, T. thiooxidans (A-SOB) と T. thioparus (N-SOB) を購入した。これらはともに 淡水種であるが, 前者は大西洋 ${ }^{8)}$ ・ベンガル湾 ${ }^{9)}$, 後者 は大西洋 ${ }^{10)}$ ・ベンガル湾9)・太平洋 ${ }^{11)}$ などで，同属同 種が検出されている。

\subsection{1 酸性硫黄酸化細菌 T. thiooxidans}

2. $85 \times 10^{7}$ cells $/ \mathrm{ml}$ T. thiooxidans 懸濁液における 304 鋼試験片 $E_{\mathrm{sp}}$ の経時変化を Fig. 7 に示す。バクテリ ア懸濁液の $\mathrm{pH}$ を硫酸により，至適值である 3 に調整す ると（の），バクテリアを含まない培養液に浸漬された 場合 $(\times)$ より, 試験終了時の $E_{\mathrm{sp}}$ は約 $100 \mathrm{mV}$ だけ貴 化していた。また，試験片によっては，同様のバクテリ 了懸濁液浸漬下で 2 日目に $E_{\mathrm{sp}}$ が約 $-400 \mathrm{mV}$ vs. SCE まで大きく卑化したこともあった。これは，導線と試験

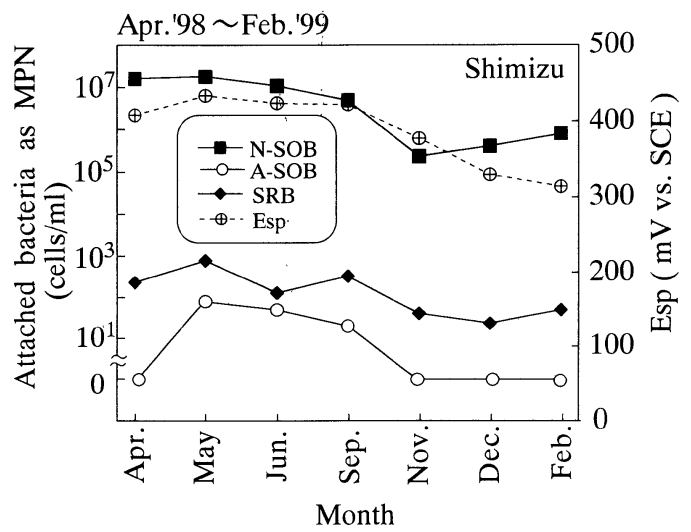

Fig.6 Monthly variation of bacteria detected on Type 316 steel with $E_{\mathrm{sp}}$ attained in natural sea water.

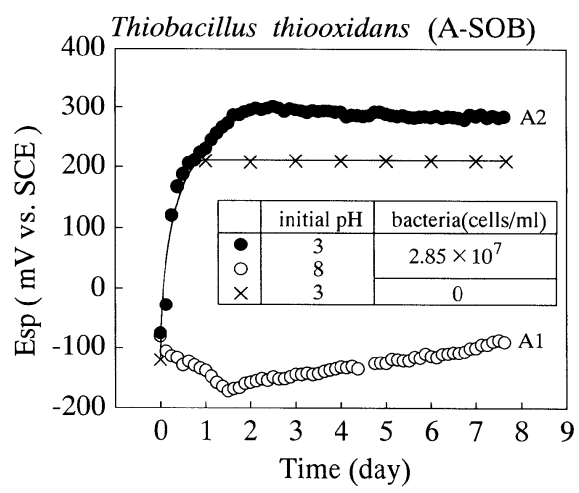

Fig.7 Time variation of $E_{\mathrm{sp}}$ for Type 304 steel in Thiobacillus thiooxidans solution and the culture medium.

片の接続部で，すきま腐食が発生したためと考えられ る。一方, 自然海水と同じ $\mathrm{pH} 8$ に調整した懸濁液中 $(O)$ では, pH 3 の時と同じバクテリア密度であるにもかか わらず，貴化効果はみられなかった。T. thiooxidans は $2 \mathrm{~S}+3 \mathrm{O}_{2}+2 \mathrm{H}_{2} \mathrm{O} \longrightarrow 2 \mathrm{H}_{2} \mathrm{SO}_{4}$ という反応によりエネ ルギーを得ている ${ }^{12)}$ ので, 生成された硫酸により, 䯚 濁液中の $\mathrm{pH}$ が低下する。実際に，Fig. 7 における試 験終了時の $\left(\mathrm{pH}, \mathrm{SO}_{4}{ }^{2-}\right.$-濃度) は, $\mathrm{pH} 3$ 䯚濁液で $(1.68,1$. $07 \%)$ ，培養液では $(3.02 ， 0.05 \%), \mathrm{pH} 8$ 懸濁液で $(7$. 12，0.66\%) であった。これをFig. 8 に示す。 $\mathrm{pH} 8$ バ クテリア懸濁液中の $\mathrm{SO}_{4}{ }^{2-}$ 濃度は, 培養液におけるそ れより高く, $\mathrm{pH} も 0.88$ 低下していたので, 至適值よ りかなりアルカリ側の $\mathrm{pH}$ においてもバクテリアの活性 は失われないことがわかる。

研磨ステンレス鋼 $E_{\mathrm{sp}}$ には, Fig. 9 の(1)線に示される

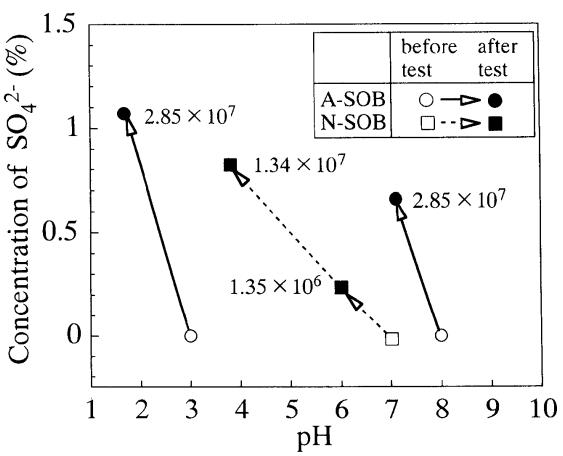

Fig.8 Change in concentration of $\mathrm{SO}_{4}{ }^{2-}$ and $\mathrm{pH}$ in Thiobacillus thiooxidans(A-SOB) and T. thioparus (N-SOB) solutions before and after the tests shown in Figures 7 and 10. The number beside each data point is density of bacteria in cells $/ \mathrm{m} l$. 
ような $\mathrm{pH}$ 依存性 ${ }^{13)}$ が存在する。この図中に Fig. 7 の 試験終了時点 $\mathrm{A} 1$ と $\mathrm{A} 2$ における到達電位と $\mathrm{pH}$ とを併

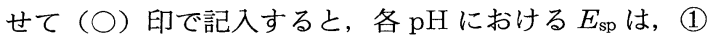
線のそれより $100 〜 150 \mathrm{mV}$ 程度低かった。これは A-SOB培養液成分の影響によるのではないかと考え, 培養液を $\mathrm{pH} 3$ から 8 まで $1 \mathrm{~N} \mathrm{NaOH}$ で順に各 $\mathrm{pH}$ に調 整し, 1 時間ずつ 316 鋼試験片を浸漬した際の $\mathrm{pH}$ と到 達 $E_{\mathrm{sp}}$ との関係を調べた。その結果を Fig. 9 の (4) 線に 示す。(1)線と傾きはほぼ同じであるが, 全体的に 100〜 $200 \mathrm{mV}$ 卑化しており,このA-SOB 培養液でみられた 卑化は培養液成分の影響と考えられる。同量のA-SOB を懸濁させたが初期 $\mathrm{pH}$ を異にする A 1 とA 2 の $E_{\mathrm{sp}}$ はともに，ほぼ (4) 線に乗っていることから， $2.85 \times 10^{7}$ cell $\mathrm{s} / \mathrm{m} l$ T. thiooxidans 尜濁液でみられる $E_{\mathrm{sp}}$ は, A 2 のそれを含めて $\mathrm{pH}$ 低下のみで説明でき, 自然海水で 従来観察してきた (2)，(3) 線のような貴化効果には寄与 しないと考えられる。

A 2 における試験片付着バクテリア密度は, およそ 8 $\times 10^{5} \mathrm{pg} / \mathrm{cm}^{2}$ であり,これを Fig. 5 に参照すると, 非 万過・0.4 $\mu \mathrm{m}$ 万過のいずれの自然海水で達成される量 より多い。すなわち,このように十分量のバクテリア密 度をもっても上述のように“貴化なし”であったことか ら，このバクテリア単独で貴化を引き起こす可能性は低 いと考えられる。

\subsection{2 中性硫黄酸化細菌 T. thioparus}

密度の異なる $T$. thioparus 懸濁液およびバクテリア を含まない培養液に浸漬した 304 鋼試験片の $E_{\mathrm{sp}}$ の経時 変化を Fig. 10 に示す。高密度懸濁液では，およそ 1 週 間で $400 \mathrm{mV}$ vs. SCE という高い $E_{\mathrm{sp}}$ まで貴化したが, 低密度懸濁液および培養液中では貴化しなかった。 $T$. thioparus は, $5 \mathrm{~S}_{2} \mathrm{O}_{3}{ }^{2-}+\mathrm{H}_{2} \mathrm{O}+4 \mathrm{O}_{2} \longrightarrow 5 \mathrm{SO}_{4}{ }^{2-}+$ $\mathrm{H}_{2} \mathrm{SO}_{4}+4 \mathrm{~S}$ という反応 ${ }^{12)}$ にしたがって硫酸を生成する ので, T. thiooxidans 同様， $\mathrm{pH}$ 低下による $E_{\mathrm{sp}}$ 貴化の

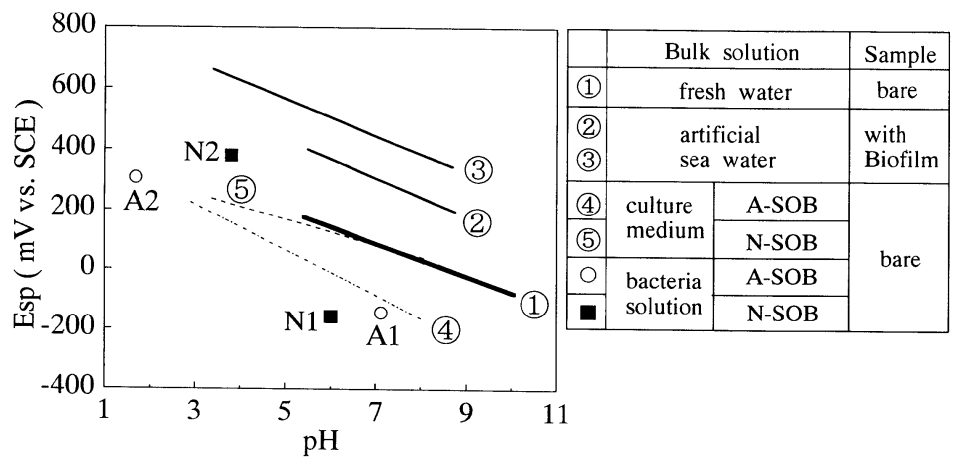

Fig.9 Effect of $\mathrm{pH}$ in $E_{\mathrm{sp}}$ for samples in various solutions. The lines (1), (2) and (3) denote the $E_{\mathrm{sp}}$ data by Reference No.1 for stainless steels.

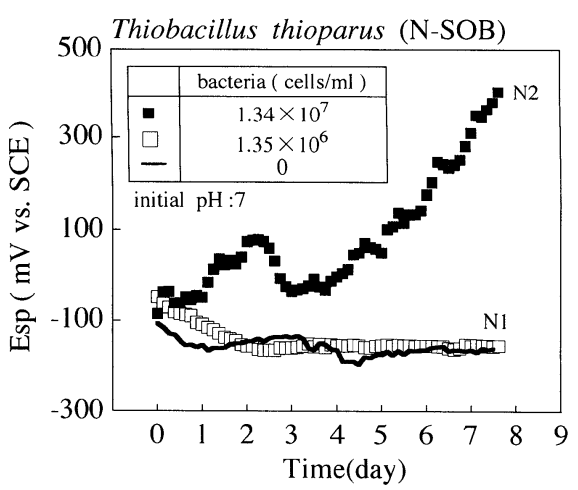

Fig.10 Time variation of $E_{\mathrm{sp}}$ for Type 304 steel in Thioibacillus thioparus solutions and the culture medium.

可能性がある。そこで, Fig.10における試駼終了時点 $\mathrm{N} 1$ と N 2 それぞれの $\mathrm{SO}_{4}{ }^{2-}$ 濃度と $\mathrm{pH}$ とを測定した ところ, Fig. 8 に示すようにバクテリア密度が高いほ ど, 生成した $\mathrm{SO}_{4}{ }^{2-}$ 濃度は高く, 同時に $\mathrm{pH}$ もより低 下することがわかった。次に N 1 と N 2 それぞれの $E_{\mathrm{sp}}$ と pH を Fig. 9 に併せて（口）印で記入した。N-SOB 用培養液中 $E_{\mathrm{sp}}$ の $\mathrm{pH}$ 依存性を示す (5) 線は (1) 線にほ ぼ重なる。バクテリア密度の低い N 1 の $E_{\mathrm{sp}}$ はこれより 卑であるが, バクテリア密度の高い N 2 の $E_{\mathrm{sp}}$ は (2) 線 で示すバイオフィルム付着試験片に近い, 高い值を示 し，実際にもバイオフィルムを認めた。すなわち， N 2 でみられた $E_{\mathrm{sp}}$ の貴化には $\mathrm{pH}$ 低下効果に加えて, 自然 海水で従来観察してきたバイオフィルム類似の寄与もあ ると思われる。

Fig.10において $1.34 \times 10^{7}$ 個 $/ \mathrm{ml}$ のT. thioparus 䀣 濁液中で, 304 鋼試験片は大きな $E_{\mathrm{sp}}$ 貴化を示したが, これより一桁少ない $1.35 \times 10^{6}$ 個 $/ \mathrm{m} l$ の T. hioparus 懸 濁液中では貴化しなかった。後者の試験終了時のバクテ リア付着密度は, LPS 值として $5 \times 10^{5}$ $\mathrm{pg} / \mathrm{cm}^{2}$ であった。Fig. 5 で示されるよ うに, 試験片の $E_{\mathrm{sp}}$ はバクテリア付着量 が多いほど高いため, より高い到達 $E_{\mathrm{sp}}$ を示した $1.34 \times 10^{7}$ 個 $/ \mathrm{m} l$ 懸濁液中で は, さらに大きな付着密度になると予測 される。 $1.35 \times 10^{6}$ 個 $/ \mathrm{ml}$ の $\mathrm{T}$. thioparus 懸濁液中で試験片へ付着した バクテリア量は $E_{\mathrm{sp}}$ 貴化のなかった N 1 で LPS 值として $5 \times 10^{5} \mathrm{pg} / \mathrm{cm}^{2}$ であっ た。この值でも, Fig. 5 の結果に参照 すると, 自然海水中では達成されない高 密度であるので, もともとの懸濁量がひ と桁多い N 2 では付着密度はさらに高 
いと推定される。したがって, T. thioparus は高密度 であれば $E_{\mathrm{sp}}$ 貴化効果があるが，清水における自然海水 浸漬下において, 単独で貴化をひきおこす可能性は低 く, 他種バクテリアやその他の微生物の共存が必要であ ると考えられる。

\section{4 バクテリア類と珪藻の共存効果}

清水にて自然海水に浸漬した試験片上には，バクテリ アのみならず, 様々な微生物が付着するが, 中でも珪藻 は季節を問わず必ず付着しており，前報 ${ }^{2}$ で示したよう に, バクテリア類と共存させることで, 自然海水浸漬下 で達成されるのと同様の大きな $E_{\mathrm{sp}}$ 貴化を再現できる。

珪藻のような微細藻類とバクテリアの間には, 互いに 他方に利益を与える「共生」のような関係や，栄養分な どについて「競合」したり「拮抗」する関係などの，様々 な相互作用が知られている ${ }^{14)}$ 。その中でも, 微細藻類 が光合成により生産した体外排出有機物 (EOC: extracellular released organic carbon）をバクテリアが好 適な増殖基質として享受するという関係は，もっとも重

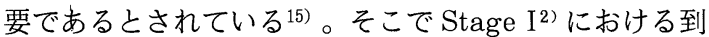
達電位（ $E_{\mathrm{sp}, \mathrm{I}}$ ） $70 \mathrm{mV}$ vs. SCE にそろえることで, ほぼ同量のバクテリア類（LPS 值として約 25,000 $\mathrm{pg} / \mathrm{cm}^{2}$ ) を付着させたと期待しうる試験片を, Stage II ${ }^{2)}$ にて様々な密度の珪藻懸濁液に浸漬することで珪藻 付着密度を変え, 10 日後のバクテリア密度と到達電位 $\left(E_{\mathrm{sp}, \mathrm{II}}\right)$ を調べた。結果を Fig.11 に示す。 $E_{\mathrm{sp}, \mathrm{II}}$ が 200 $\mathrm{mV}$ vs. SCE 程度までは, 付着珪藻密度が増すほどバ クテリア密度も高くなっており, 珪藻がバクテリアの増 殖に寄与していると考えられる。しかし，それ以上の $E_{\mathrm{sp}, \amalg}$ では, 付着珪藻密度が増加しているにもかかわら ず，バクテリア付着密度は約 $3.5 \times 10^{4} \mathrm{pg} / \mathrm{cm}^{2}$ の一定

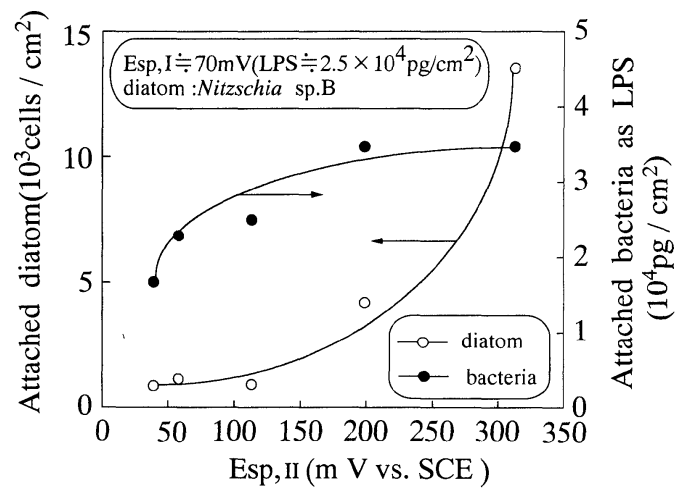

Fig.11 Effect of attached diatom and bacteria on $E_{\mathrm{sp}, \text { II }}$ attained at the end of Stage II test conducted in various concentration of diatom solution with an initial condition for bacteria as $E_{\mathrm{sp}, \mathrm{I}}$ of $70 \mathrm{mV}$ or LPS of $2.5 \times 10^{4} \mathrm{pg} / \mathrm{cm}^{2}$.
値にとどまっている。

次に, Stage I 処理時間を変えることで, $E_{\mathrm{sp}, \mathrm{I}}$ 值に幅 をもたせた試験片（ $E_{\mathrm{sp}, 1}=19 \sim 73 \mathrm{mV}$ vs. SCE・LPS 值：20,000〜25, $000 \mathrm{pg} / \mathrm{cm}^{2}$ ) を Stage II において Fig.11 と同様に様々な密度の珪藻懸濁液に浸漬した。 試験終了時の $E_{\mathrm{sp}, \mathrm{II}}$ とバクテリア付着密度および珪藻付 着密度の関係を Fig.12 に示す。この試験においてもバ クテリア密度は約 $3.5 \times 10^{4} \mathrm{pg} / \mathrm{cm}^{2}$ を越えなかった。 同じバクテリア密度で比較すると, 珪藻付着密度が高い ほど， $E_{\mathrm{sp}}$ はより大きく貴化している。すなわち，珪藻 の寄与が大きく, 同 $350 \mathrm{mV}$ 以上には $15 \cdot 10^{3} \mathrm{cell} / \mathrm{cm}^{2}$ の珪藻の付着が必要とよめる。

\section{4. まとめ}

（1） a）自然海水または b） $0.4 \mu \mathrm{m}$ のフィルターで ろ過することで生物としてはバクテリア類のみを含むと 期待される海水, に浸漬した 316 鋼試験片の到達 $E_{\mathrm{sp}}$ と バクテリア付着量との関係を調査した。バクテリア類単 独 b)でも約 $200 \mathrm{mV}$ vs. SCE までは貴化するが， 400 $\mathrm{mV}$ vs. SCE という高い $E_{\mathrm{sp}}$ に達する貴化は a）に限 られ，他の微生物の共存が必要であることがわかった。

（2）自然海水中で貴化した 316 鋼試験片に付着した バクテリア類のうち, 酸性および中性硫黄酸化細菌・硫 酸塩還元細菌・鉄酸化細菌の調査をおこなった。鉄酸化 細菌以外の細菌が検出され, 特に中性硫黄酸化細菌が年 間を通じて多かった。

（3）酸性硫黄酸化細菌 Thiobacillus thiooxidans および中性硫黄酸化細菌 T. thioparus $の E_{\mathrm{sp}}$ 貴化可能 性を調べた。前者は $E_{\mathrm{sp}}$ 貴化効果を認めなかった。後者 は自然海水浸漬下で期待されるよりは著しく高いバクテ リア量で一定の貴化効果を示したが，LPS 值として 2 $\sim 3 \times 10^{5} \mathrm{pg} / \mathrm{cm}^{2}$ 以下の通常の量では有意な貴化効果

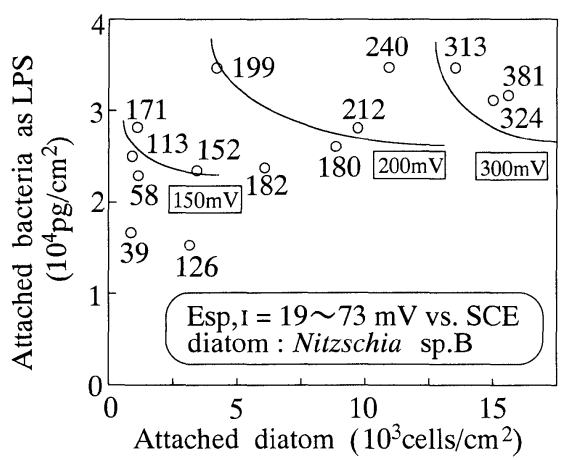

Fig.12 $E_{\mathrm{sp}, \text { II }}$ in terms of attached bacteria and diatom attained at the end of Stage II test. The number beside each data point is $E_{\mathrm{sp}, \text { II }}$ in $\mathrm{mV}$ vs. SCE. 
を示さなかった。

（4） あらかじめ自然海水に短期間浸漬することでバ クテリア類を付着させた試験片を, 純粋培養した種々濃 度の珪藻（Nitzschia sp. B）䀣濁液に移して, 後の到 達電位 $E_{\mathrm{sp}, \mathrm{II}}$ に及ぼす付着バクテリア量（LPS 值）と付 着珪藻との影響を調べた。バクテリア量は, 約 $3.5 \times$ $10^{4} \mathrm{pg} / \mathrm{cm}^{2}$ を越えず, $200 \mathrm{mV}$ 以上さらに $350 \mathrm{mV}$ vs. SCE 以上の高い $E_{\mathrm{sp}, \amalg}$ に達するには, 珪藻の寄与が 必要なことがわかった。

本研究の自然海水浸漬に関し, 東京商船大学清水臨海 実験実習所を使用させていただきました。同学の鈴木揚 之助教授・元田慎一助教授, および実験所の小林充氏に 深く感謝致します。さらに本研究に熱心に協力された上 山健一氏 (現在, 東京大学大学院), 嶋田葵氏 (同, 木 下プロダクション), 川村久美子秘書に厚く感謝しま す。

(Manuscript received March 30, 1999 ; in final form May 20, 1999)

\section{文献}

1) 石原靖子, 元田慎一, 鈴木揚之助, 辻川茂男 : 材 料と環境，44，355（1995）.

2 ）石原靖子, 辻川茂男：材料之環境, 47, 260（1998）.
3) 門田 元, 多賀信夫編：「海洋微生物研究法」, p 43, 学会出版センター (1985).

4 ) 微生物生態研究会編:「微生物の生態 10-微生物 生態論の諸側面」, p. 312, 学会出版センター (1982).

5 ) N. Lazaroff: J. Bacteriol., 85, 78 (1963).

$6)$ J. H. Tuttle and H. W. Jannasch: Limnor. Oceanogr., 17, 532 (1972).

7 ) 土㖶微生物研究会編：「土㙵微生物研究法」, p. 312，養賢堂 (1992).

8 ) R. C. Tilton, G. J. Stewart and G. E. Tones: Can. J. Microbiol., 13, 1529 (1967).

9) M. Eashwar, S. Maruthamuthu and Balakrishnan: Indian J. Mar. Sci., 19, 107(1990).

10) R. C. Tilton, A. B. Cobet and G. E. Jones: Can. J. Microbiol., 13, 1521 (1967).

11) F. W. Adair and K. Gundersen: Can. J. Microbiol., 15, 345 (1969).

12）R.キャンベル：「基礎微生物学 5 微生物生態 学」, p.82, 培風館 (1985).

13）中山元, 福田敬則, 明石正恒：「腐食防食' 93 講 演集」, p.415（1993）.

14）清水 潮編：「微生物の共生系〈微生物の生態 21〉」, p. 1, 学会出版セン夕ー（1995）.

15）清水 潮編：「海洋微生物とバイオテクノロ ジー」, p. 256, 技報堂出版 (1991).

16）門田 元・多賀信夫編:「海洋微生物研究法」, p. 120 , 学会出版センター (1985). 